\title{
Institutional transition: Internal migration, the propiska, and post-socialist urban change in Bishkek, Kyrgyzstan
}

Urban Studies

2016, Vol. 53(10) 2175-2191

(c) Urban Studies Journal Limited 2015 Reprints and permissions: sagepub.co.uk/journalsPermissions.nav DOI: 10.1 I $77 / 0042098015587252$ usj.sagepub.com

@SAGE

\author{
Craig Hatcher \\ University of Zurich, Switzerland
}

\section{Susan Thieme}

Freie Universitaet Berlin, Germany

\begin{abstract}
Since the collapse of the Soviet Union in the early 1990s, there has been remarkable enthusiasm for theorising how transitional processes have unfolded in post-socialist cities. In seeking to extend literature that uses the post-socialist condition as a tool for theory building, we draw attention to the ongoing processes of institutional change in post-socialist cities. In doing so, we reject a 'top-down' perspective and examine how these institutional transitions are shaped through processes of 'domestication', negotiation and contestation between different interest groups in the city. We develop our argument, by drawing attention to the local political debates surrounding the propiska in Bishkek, Kyrgyzstan. The propiska developed throughout the Soviet Union to control internal migration and is still used today in a less restrictive form. By discussing our case study, we hope to foster attention towards the ongoing contested processes of institutional transition in post-socialist cities.
\end{abstract}

\section{Keywords}

Bishkek, governance, institution, internal migration, Kyrgyzstan, legacy, post-socialist change, property, urbanisation and developing countries

Received February 20I4; accepted April 2015

\section{Introduction}

An active research community continues to theorise changes that have been occurring in post-socialist cities since the dissolution of the Soviet Union and the destruction of the Berlin Wall (Andrusz et al., 1996; Darieva et al., 2012; Gentile et al., 2012; Golubchikov et al., 2014; Grubbauer and Kusiak, 2012; Tsenkova and Nedović-Budić, 2006). Within

\section{Corresponding author:}

Craig Hatcher, University of Zurich, Department of Geography, Winterthurerstrasse 190, Zurich 8057, Switzerland.

Email: craig.hatcher@geo.uzh.ch 
this literature, an important focus remains on the tensions between Soviet 'legacies' or the 'frozen mirrors of socialism' (Sýkora and Bouzarovski, 2012: 45) and post-socialist changes that produce contemporary forms of urban inequality.

Studies theorising the transformation of urban space in post-socialist contexts emphasise the complexities of these changes. Post-socialist transformation is theorised as multiple and operating at different scales and temporalities, from the institutional level to the practices of individuals, firms and organisations and reconfigurations of the built environment (Sýkora and Bouzarovski, 2012). The post-socialist city is characterised as continually unfolding under processes of 'heteropolitanisation' that reflect both the mixture of path-dependencies and transitioninduced factors (Gentile et al., 2012). It is this mixing of the old and new that Golubchikov et al. (2014) characterise as the 'hybrid spatialities' of transition, whereby so-called 'legacies' of socialism have become incorporated and hybridised within the logics of capitalism.

In building on this literature, we aim to highlight the mutual and interdependent relation between urban space and institutions in post-socialist cities. As Taşan-Kok (2006: 51) notes, the realignment of institutional structures towards free market mechanisms and democratic structures 'have had pronounced spatial consequences in post-socialist cities'. As well as noting these spatial changes, we also highlight the reciprocity of this relationship by reflecting on how institutions adapt to wider transformations in the post-socialist city and, in the context of our case study, as a result of changes in property relations following privatisation programmes in the 1990s (Marcuse, 2011). In examining this relation between urban space and the institution, we aim to foreground new forms of inequalities emerging in the post-socialist city.
In understanding the mutual relation between urban space and the institution, we draw on a broader and localised definition of the 'institution' beyond the short term political and economic restructuring evident, for example, in the structural adjustment programmes of the early 1990s, to include a combination of rules, laws, internal procedures and informal values and norms (North, 1990). In doing so, we argue that not only is institutional transition ongoing in the post-socialist city (see Haase et al., 2011; Sýkora and Bouzarovski, 2012; Cities After Transition (http://citiesaftertransition. webnode.cz/); c.f. Leetmaa et al., 2009 on suburbanisation), but also how institutional transition is subject to multiple framings by different interest groups.

In conceptualising institutional change in the context of post-socialist cities, we draw on our case study of the propiska. ${ }^{1}$ The propiska was an institutional mechanism first introduced in the Soviet Union in 1932 to regulate internal migration. As with other postsocialist countries - with Russia being a more popular research example (Höjdestrand, 2003; Light, 2012; Schaible, 2001) - internal migration continues to be monitored by an administrative system of registration (registratsiya) that is still commonly referred to by its Soviet name, the propiska.

Institutional changes of the propiska within the context of urban transformation are explored in the city of Bishkek, the capital of Kyrgyzstan. The registration system, as was also the case in the Soviet period, is important in the everyday life of the Kyrgyz citizen and is particularly relevant in Bishkek where the majority of internal migrants move to in search of work, to study, or a combination of both. A registered status in Bishkek is required to officially access basic state services (health care, education, pensions and child support), to vote and is sometimes a requirement for public-sector jobs, while more recently it has also become 
a pre-requisite for taking out bank loans and starting a business. Despite these encompassing aspects, approximately $20 \%$ of Bishkek's population is estimated to have 'unregistered' status in the city which, for some, restricts their right to access basic urban services, to vote, obtain credit and formally set up a business (Azimov and Azimov, 2009).

In analysing the propiska system in relation to the wider dynamics of post-socialist urban change in Bishkek we ask the following questions:

- How are institutional changes in relation to internal migration enacted in legislation and how are these changes perceived, negotiated and 'domesticated' by different actors in Bishkek?

- How are these institutional changes nested in wider transformations unfolding in the post-socialist city, particularly in relation to privatisation of property, and how does this relate to the marginalisation of certain groups?

In answering these questions we draw attention to Bishkek, a city that has remained relatively underexplored in studies on post-socialism save for some important research on migration and the related growth of informal settlements (Flynn and Kosmarskaya, 2012; Hatcher, 2015; Sanghera et al., 2012), on emerging urban youth identity (Ibold, 2010; Schroeder, 2010), and housing policies in relation to ongoing privatisation (Hatcher, forthcoming). While a small body of literature is emerging on other cities in Central Asia (Alexander et al., 2007; Darieva et al., 2012; Gentile and Tammaru, 2006), studies on post-socialist cities tend to remain geographically focused on Eastern and Central Europe. Thus, we seek to foreground Bishkek in order to expand on the empirical bias evident in studies on post-socialist cities.
The paper is structured as follows. In the next section, we discuss how theories on post-socialist change have questioned universalising principles (Hörschelmann and Stenning, 2008) and instead note how macro-level policies are negotiated, 'domesticated' and redefined at the local level (Smith and Rochovská, 2007; Stenning et al., 2010). We note how the unfolding of these processes at the local level provides a useful conceptual starting point for understanding the wider dynamics of institutional change in post-socialist cities. After discussing our methodology, we introduce the propiska and empirical material from the first author's field research in Bishkek. First, we examine the regulation of internal migration from a historical perspective, second, the power struggles between different urban actors in framing institutional change and third, how spatial changes in the postsocialist city, namely related to property, reshape the role of the propiska towards a capitalist logic.

\section{Institutional change in the post- socialist city}

With the accession in 2004 of seven former 'Eastern Bloc' countries to the European Union, scholars and policy-makers have tentatively questioned addressing the issues that these countries are facing 'after the transition' (Cities After Transition (http://citie saftertransition.webnode.cz/); Leetmaa et al., 2009; Stenning et al., 2010). As an interesting contribution to these debates, studies on postsocialist cities retain the importance of using 'post-socialism' as a lens of inquiry but expand on the meanings behind change. Sýkora and Bouzarovski (2012: 45) switch between 'transition' and 'transformation' in their proposed framework for theorising post-socialist urban change. While transition is typically 'associated with the neoliberal agenda, based on the radical replacement of 
the basic political and economic institutions of socialism with democratic and market arrangements', transformation, on the other hand, highlights the 'hybrid nature of postcommunist realities with respect to the recombination of socialist and capitalist elements'. Unlike earlier teleological approaches towards transition, transformation does not take place in a vacuum or on a tabula rasa, rather it is contextual and reliant on inherited structures (Stark and Bruszt, 2001). It is the blending of these inherited structures with neoliberal doctrine that leads to the workings of such socialist legacies playing a different and contemporary role in the post-socialist setting (Golubchikov and Phelps, 2011).

Studies on urban change have therefore highlighted an internalisation of a neoliberal doctrine that combines with persistent socialist elements (Herrschel, 2007: 440). Accordingly, " $\mathrm{t}]$ he narratives and legacies of the past - including those that hark back to the era before socialism - articulate with contemporary processes of globalization and neoliberalization' (Stenning et al., 2010: 6). Socialist structures remain embedded in government apparatus that in other aspects are 'progressing' under the principles of freemarket capitalism, attitudes continue to prevail that could be perceived as 'Soviet', state structures change while attitudes remain and some aspects are unnoticed or considered neither socialist nor post-socialist but just there as a backdrop to everyday life.

Recent debates on conceptualising postsocialist change in geography (Hörschelmann and Stenning, 2008; Smith and Rochovská, 2007; Stenning et al., 2010) have drawn on literature in anthropology (Burawoy and Verdery, 1999; Hann et al., 2002) to understand how macro level policies interact with everyday experiences (Creed, 1999; Stenning et al., 2010; Verdery, 1996). The large scale processes of transition are therefore responded to and (re)produced by specific actors in specific locations
(Hörschelmann and Stenning, 2008). A research agenda has developed that realises the critical importance of understanding how broad, macro-economic policies affect people that live through and within them (Stenning, 2000). Stenning et al. (2010) emphasise that not only are individuals subject to these policies, but they also play an active role in negotiating, contesting and constructing these, while adapting them to their personal circumstances. Thus, the neoliberal economic plans of the post-socialist era are 'domesticated' and exist through the practices of everyday life (Stenning et al., 2010), just like the policies implemented during the socialist era varied locally as they were negotiated, constituted and made possible through everyday practices (Creed 1999).

A focus on urban change in postsocialist contexts examines unfolding transformations at the local level and thus, offers a more nuanced perspective on how policies are embedded within power constellations. Reading post-socialism through the 'urban' magnifies the 'recombinant' (Stark, 1996) or 'fuzzy' (Verdery, 1999) nature of urban policies as they merge with the 'continuities' of socialism and the 'changes' of neoliberalism. As Golubchikov and Phelps (2011: 428) note in their analysis on the broader institutional context of post-socialist urbanisation:

If we unpack the local 'consensuses' of postsocialist societies for scrutiny, we will find the contentious processes of institutional configurations and reconfigurations with old and new, socialist, pre-socialist and post-socialist elements co-existing, interplaying and conflicting with each other.

Soviet institutions have mutated to incorporate neoliberal characteristics while neoliberal policies are manipulated and shaped to 'fit' with prevailing 'legacies'. Understanding this connection between 'legacy', and 
'change' is dependent on who is involved in the implementation of such urban policies and for what reasons and how they go about doing this.

Following a brief discussion of our methodology, the next section outlines institutional change in relation to the propiska by detailing its historical development, the actors involved in proposing reform and how this institutional change is nested within a broader frame of post-socialist change in the city.

\section{Methodology}

The data collection for this paper was carried out by the first author between 2011 and 2013. Semi-structured interviews were held with a range of different individuals who have varying involvement in the propiska system. This included internal migrants, government officials, civil servants working at local registration offices, representatives of non-governmental organisations (NGOs) and activists who were proposing reforms to change the current system $(n=53)$.

Registration with the local authorities in Bishkek can be a time consuming process requiring the collection of certified documents from various agencies in the city and from the migrant's home town or village. The first author therefore 'shadowed' applicants that were in the process of registering with the local authorities in Bishkek. Shadowing applicants through the propiska system ensured that we developed a full understanding of the official practices of registration together with the unofficial aspects and especially those characteristics that were difficult to define as one or the other. This involved queuing with the applicants at passport and housing offices as they acquired documents, visiting individuals and organisations to secure a 'fake' address required to register, obtaining seals from notaries and depositing payments at banks. The first author also attended various roundtable discussions on proposing reforms to the existing system of registration as a non-participant observer. Interviews and discussions during the shadowing process were mainly in Russian or Kyrgyz and translated into English with the assistance of a translator.

Secondary sources were analysed by the first author, including legal and archival documents and newspapers. This involved a legal analysis of relevant pieces of legislation concerning the propiska system. An online legal database (TOKTOM, http://www.toktom.kg/) was used to access Kyrgyz legislation and to follow the enactment and repeal procedures of different laws. Archival research was used largely for accessing local public information newspaper articles on the propiska which reported on the relevant legal changes enacted in Kyrgyzstan between 1940 and 1990.

\section{The propiska and post-socialist urban change}

Kyrgyzstan has been independent for nearly 20 years - and we still have this Soviet system! (Interview with local NGO director, 2011)

We can perhaps acknowledge an era of 'post-institutional transition' (Leetmaa et al., 2009) or a time period of 'after-institutional-transition' (Sýkora and Bouzarovski, 2012) in post-socialist cities if we take institutional transition to mean the short-term political and economic reforms initiated by 'shock therapy' policies of structural adjustment programmes in the 1990s that saw, among other aspects, the mass privatisation of housing. In this paper, we take Douglass North's (1990: 3) broader definition of institutions as "the "rules of the game", consisting of both the formal legal rules and the informal social norms that govern individual behaviour and structure social interactions.' 
In developing a local or 'domesticated' understanding of institutional transition, we take institutions to therefore mean a combination of formal rules, laws, contracts, internal procedures and informal values, morals and norms. Writing from an urban perspective, Amin and Thrift (2002: 72) note that ' $[\mathrm{t}]$ he rich and varied ecology of life in cities presses for institutionalisation, through the opportunity for collective organisation offered by scale and density, but also the need for orientation and rules in a bewilderingly complex and varied environment.' Institutions therefore develop to control societal and urban complexity and are formed and re-formed as a set of practices that are fragmentary, non-coordinated and contested through local-level power struggles (Hansen and Stepputat, 2001). Cities are thus especially dense institutional assemblages that encompass the material and nonmaterial as evident in the physical structure of institutions such as hospitals, schools and local government offices as well as the ideas and discourse that co-produce such institutions, together with the role of various individuals and groups.

Taking this broader definition, we first analyse institutional change and proposed change in relation to the propiska by drawing on its different framings stretching across historical and contemporary legal definitions and understandings of local interest groups, international organisations and residents of the city. In the next section we discuss the introduction of the propiska throughout the Soviet Union from the 1930s and, more specifically, in Bishkek. ${ }^{2}$ In doing so, we draw on both historical and contemporary literature on the development of the propiska and begin to introduce empirical findings from archival and legal research that focus on this development in Kyrgyzstan. This is followed by an analysis of how the propiska is 'domesticated' in everyday administrative processes and in terms of proposing reform. The final section challenges some of these dominant representations of the propiska to understand the 'hybrid spatialities' (Golubchikov et al., 2014) of institutional change unfolding in post-socialist cities. We explore these 'hybrid spatialities' by linking changes in the propiska to outcomes of property privatisation programmes introduced during Kyrgyzstan's early independence years.

\section{Kyrgyzstan and the Soviet propiska: A historical perspective}

The registration system authorised the holder of a propiska to work in a particular town and reside at a specified address (Light, 2012). ${ }^{3}$ Reasons for the propiska system's implementation during Stalin's era vary. According to legal scholar, Damian Schaible (2001), the system was initially implemented to 'tie' collective farm workers and other rural dwellers to the land and restrict mass migration to cities. Unlike urban areas, passportisation was not extended to individuals living in rural areas until 1974, therefore restricting their access to 'passportised regime areas' - notably cities, industrial centres outside of cities, large towns and frontier zones (Toktosunov, 1975). This not only restricted the physical movement of rural dwellers but also the possibility of finding a job and living in the city where individuals were comparatively better off, especially during the widespread famines of the 1930s (Matthews, 1993). Kessler (2001: 478) also argues that the system was introduced as an instrument of repression and police control and, in the short run, more crudely as a purging tool' as kulaks and other individuals that fell outside the socialist ideal were cleansed from cities and other regime areas. ${ }^{4}$ The propiska system then later developed to serve as an administrative tool throughout the Soviet Union, whereby the payment of pensions and social security benefits as well as access to local polyclinics (health centres) 
were all dependent on the individual's registered address.

Larger Soviet cities such as Moscow and Saint Petersburg as well as capitals of the republics, such as Bishkek, often implemented their own regulations in relation to the propiska thereby allowing them to expel people from the city who 'avoided socially useful work', whose behaviour was 'unworthy', and who 'infringed the rules of the socialist community' (Matthews, 1993: 7; Sovetskaya Kirgizia, 1948). This created what Höjdestrand (2003) defines as a 'territorial stratification' between those living in privileged city regions and others living outside of these regime areas often in rural areas of the country. As one local Bishkek newspaper noted, the 'city propiska' became a 'cherished stamp' in one's passport (Vecherniy Frunze, 1990). Residence in the city was regarded as a privilege whereby urban living was 'seen as the highest form of socialist life' and the town was 'the best place where socialist consciousness [could] develop the necessary environment for achieving the perfection of a socialist society' (French and Hamilton, 1979: 7).

In the early 1990s, just before Kyrgyzstan's independence and in the era of Gorbachev's perestroika (restructuring) reforms, attitudes towards the propiska began to relax in Bishkek, yet stringent restrictions on internal migrants' rights remained in place. Owing to a labour and housing shortage in the city, directors of enterprises began to hire workers who were not officially registered in Bishkek. Nonetheless, as one local newspaper noted, 'such families live without any rights at relatives, friends, temporary houses ... These people have many problems: they cannot get sugar ration tickets nor be admitted to a kindergarten or hospital' (Vecherniy Frunze, 1990). It was not until after the dissolution of the Soviet Union that the restrictive nature of the propiska was - officially, at least - gradually reduced, giving citizens the right to choose their place of residence.

These institutional changes were often implemented reluctantly by municipalities. In larger cities such as Moscow many more established residents were unhappy with the increasing number of migrants moving to the city, especially from Central Asian countries such as Kyrgyzstan and Tajikistan (Bovt, 2013). Similar sentiments over 'protecting' the city exist in Bishkek, although this is largely in relation to internal migrants moving to the city rather than international migrants, as is the case with Russian cities. The (internal) migrant population of Bishkek has increased most noticeably since the collapse of the Soviet Union. Between 1989 and 1999 the city's population grew from 619,900 to 762,300 and to 835,300 in 2009 (National Statistical Committee of the Kyrgyz Republic, 2009) at a time when the largely urban, ethnic Russian population were leaving the country to pursue citizenship and perceived better opportunities in Russia. ${ }^{5}$ This led to what established Bishkek residents describe as the 'ruralisation' of Bishkek, especially pointing to the urban sprawl on the outskirts of the city that saw the development of novostroikas (literally meaning 'new constructions'). Novostroikas are informal settlements that emerged in the late 1980s when the Soviet administration, as a means of tackling the housing shortage in the city, began to distribute land plots to internal migrants and allow them to construct their own housing. Such housing shortages were systemic throughout the Soviet Union at the time (Stanilov, 2007), and especially in Central Asian cities where there were higher levels of overcrowding than in other Soviet cities (Morton and Stuart, 1984). ${ }^{6}$ This initial state-sanctioned urban sprawl was subsequently followed by two waves of 'illegal' land squatting first in the early 1990s after the collapse of the Soviet Union and second 
in the aftermath of the Tulip Revolution in 2005.

Established ethnic Kyrgyz and Russian residents living in Bishkek collectively disassociate themselves from those individuals who have recently moved to the city from rural areas. Bishkek residents tend to perceive these rural dwellers as uncultured and unaccustomed to urban living (see Schroeder, 2010), while tensions exist in their 'illegal' taking of land that belongs to the city's Land Redistribution Fund; land that was reserved for Bishkek residents during the privatisation process. In linking this labelling of 'illegality' to the propiska, one government official noted:

\begin{abstract}
All respectable citizens have a propiska. This problem [with the propiska] is mainly an issue for residents living in novostroikas, but most novostroikas are illegal. People just seized the lands ... it is not their land ... [and so] respectable citizens do not have such problems with the propiska.
\end{abstract}

It was also noted how the internal migrants had, as part of the privatisation process, typically received land from the state in rural areas but as one respondent noted: 'they're just too lazy to work on the land, so they come and earn easy money in the city's bazaar [market]'. Yet reportedly, the distribution of this agricultural land by local village governments (ayil okmotu in Kyrgyz) has been inequitable and lacked transparency while a significant proportion is classified as severely degraded, suffering from erosion and requiring substantial irrigation investment (USAID, 2011), all factors that have contributed to processes of migration to Bishkek, and beyond to Russia and Kazakhstan.

\section{Domesticating the Bishkek propiska and framing its reform}

Institutional changes and how they are experienced differently - or 'domesticated' as they are lived, negotiated and resisted - by different individuals (Stenning et al., 2010) highlights the need to examine the propiska through the everyday, mundane practices of those subject to it. In doing so, the 'topdown' perspective to transition is replaced with how institutions are produced through networks of individuals, policies and practices operating at different scales. In this section, we introduce formal changes to the propiska enacted through legislation, how these formal rules are 'domesticated', and how possible future changes are envisaged through the different actors proposing reform or, conversely, in maintaining the existing system. We do this in order to demonstrate how institutional transition is still ongoing and also how such change is negotiated or 'domesticated' by different urban groups and identities.

The restrictive nature of the propiska system was formally altered through Kyrgyzstan's newly adopted constitution first drafted in 1993. This incorporated international human rights standards that entitled all Kyrgyz citizens to the 'liberty of movement, freedom to choose his [sic] destination and residence through the territory of the Kyrgyz Republic' (Article 14 of Constitution of the Kyrgyz Republic, 5 May 1993). The subsequent Law on Internal Migration (IM, 30 July 2002, N. 133), enacted by a presidential decree in 2002, established more specific rights and duties for internal migrants. Depending on their intended length of stay, a migrant registers temporarily (usually for a six-month period) or permanently (Article 12, Law on IM, 30 July 2002, N. 133). An applicant who wishes to obtain a Bishkek propiska must provide, among other identification documents, proof of where they are staying temporarily or moving to permanently (Article 16, Law on IM, 30 July 2002, N. 133). Proof of residence is usually met by written consent of a willing property owner (often a family 
member, or the applicant themselves if they own the property). A tenant must enter into a written tenancy agreement with the landlord (Article 16, Law on IM, 30 July 2002, N. 133). The property owner giving permission to register must also attend one of the registration offices with the applicant and provide their own passport. The address is then recorded on the applicant's identification card or, if the applicant is only staying temporarily, on an officially stamped document.

Respondents shadowed during the registration process in Bishkek highlighted the individual nature of obtaining necessary documents, which was often dependent on relationships established with employees of registration centres. One respondent described an exchange with a housing official in relation to a certificate she required to register with the city's authorities:

The woman in the [housing] office asked me: 'Is it legal or illegal?' We said, 'It's illegal.' She immediately understood and said, 'Do you want me to process your documents through our accounts department? If they are processed here, one more person will be added to your utility services and you will have to pay more for water, and for some other things,' so we said, 'Let's make it illegal without processing it through the accounts department.' The woman said, 'OK, fine.'

The challenges of the propiska are, for some individuals, negotiable. Days before attending the housing office, the respondent noted how she had made several phone calls and visited friends and old contacts to establish who knew of an acquaintance working within the registration system. Circumventing the requirements of the propiska system is possible for those who can afford to pay or know the right contacts. For them, the propiska is seen more as a superfluous and out-dated piece of bureaucracy from the Soviet period, which is ignored or negotiated at an everyday level when the individual need arises. For others, notably poorer internal migrants from rural areas, a lack of a valid propiska means paying costly bribes to school teachers, doctors and low-paid state officials in order to access urban services or obtain a 'fake' propiska.

Groups advocating reform of the system, typically local NGOs and activists, framed the propiska system as 'Soviet' and thus 'out of place' in modern Kyrgyzstan as a means to advocate a need or a reason for it to change. As a government strategy document on the propiska noted:

Kyrgyzstan appears today before new global challenges .... including the globalization of the economy, mass labour migration, and international terrorism. Their impact on Kyrgyzstan creates new threats. Working with them requires innovative approaches and new solutions. (SRS, 2011)

One director of an NGO stressed how the registration system was interfering with Kyrgyzstan's transition, and in particular its economic development, by creating additional hurdles required to open a business and restricting labour mobility.

The local NGO, along with other international NGOs and independent activists and some politicians also demonstrated how the current system curtailed individual liberties. One activist linked this curtailment of rights as a negative 'atavism' - a throwback - of the Soviet era:

Why do we say that the propiska is a product of the Soviet time? Because during that time people used to live under the control of the government: we didn't have freedom! And why should we still continue to live in that way when we got independence a long time ago ... I want to feel free myself and move from one place in Kyrgyzstan and still get free access to any social service in any place ... so we should refuse this Soviet system. This system was strict and people had limited rights. 
The activist linked the current registration system with what are more commonly regarded as the negative aspects of the Soviet period. The migrants we interviewed often cited the Soviet period as, on the one hand, a time when access to free healthcare and employment was guaranteed but on the other hand, when civil society movements were restricted, individualism was discouraged, and political rights were curtailed.

Others emphasised the importance of the propiska but noted a simplified system was needed. The propiska remains embedded in administrative structures, which, as one employee of a passport office noted, would cause 'frightful disorder if you were to completely do away with [it].' Rather than abolish it altogether, computerisation of the system was proposed as a means of pushing the system into the modern era. As one politician noted: 'we must move away from Soviet principles and move forward given that we live in an age of information technologies.' The registration system continues to operate today as a heavily manual mechanism with little technical input. This lack of computerisation means that all documents have to be filed in person at one of the city's three main registration centres. A lawyer seeking to simplify but maintain the system of propiska noted:

If you want to change your address ... you need to collect and turn in many different types of documentation, and the entire process will take at least one month. That's where the problem lies, not with the propiska [but with] the waiting and collecting of all the documents, that is where the headaches, discomfort and annoyances are.

Each applicant was required not only to attend a registration centre in person but also local government offices in the region where they were moving from to collect documents needed to register at their new address. This was not only time consuming but could involve an expensive trip across the country in order to return to their place of origin and collect the necessary documents.

The computerisation of the registration system was partly put into practice in January 2012 when the State Registration Service (SRS; Gosudarstvennaya Registratsionnaya Sluzhba), a newly established government department, assigned with the role of updating the propiska system and, in particular, eliminating its notoriously corrupt practices, opened a new registration centre in Bishkek (SRS, 2011). Respondents highlighted that introducing a computerised system is perceived to be the one, and often only means, of pushing the current system up to modern standards. Yet, as an employee of the new registration centre noted, the practices of the staff, including corruption, and the mechanisms of the propiska simply transfer to an electronic system.

For Bishkek old-timers (starozhily), control of migration and crime were commonly cited reasons for why Kyrgyzstan, and especially, Bishkek, needs to retain its current system of registration. Several respondents noted that the propiska was needed for safety issues in the city as "criminal acts ... were normally done by migrants' and the system of registration allowed for easier pinpointing of criminals. The linking of criminality to internal migrants chimes with a study by Flynn et al. (2014: 1514) on nostalgic memories of Frunze and how 'long term residents, both Kyrgyz and Russian, tend to view their worsening life conditions through a prism of an invasion by migrants.'

While migration was originally restricted in the Soviet Union to serve the needs of the planned economy and avoid the 'negative aspects of capitalist migration' (Buckley, 1995), the current system of registration no longer directly restricts migration. Nevertheless, this earlier Soviet curtailment of movement is still cited by some Bishkek 
old-timers as a reason why the propiska system is needed. As the head of one parliamentary committee working on migration issues informed us: 'every person has to have one propiska to regulate the flow of people migrating.' There is thus a continuing perception that the registration system controls the movement of migrants to Bishkek, as was the case during the Soviet Union. Yet, as we attempt to show below, these dominant framings that focus on the 'legacy' of the propiska, or on its historical purpose, can obfuscate other contemporary processes of urban change that reveal new spatial inequalities.

\section{The propiska and post-socialist property relations in the city}

The 'legacy' of the propiska has become incorporated within wider neoliberal logics of institutional change in the city, especially in relation to the privatisation of property. In this final empirical section, we explore the nested relationship between the propiska and wider property transformations as a means to understand contemporary productions of post-socialist inequalities.

Moving to the city during the Soviet period was not an easy task. As Morton (1980: 237) writing during the Soviet period notes, '[e]very step in the process from acquiring a propiska to receiving comfortable housing is measurable in years of anguish, aggravation, discouragement, and resignation.' The right to live in the city required a propiska; yet obtaining one was dependent on receiving a property in the city, which was normally dependent on gaining employment there. Several options existed for those who wanted to move to the city from rural areas or smaller cities: if possible, live with relatives or acquaintances, gain employment with an organisation that provided housing to its employees, or sublet an apartment. These inevitable complications led some individuals desperate to live or stay in a Soviet city to pursue fraudulent strategies such as obtaining a propiska through 'sham' marriages or by bribing officials working in the local administration offices (Buckley, 1995). As one local newspaper article noted in highlighting the crack-down on propiska fraud, individuals who had a property in Bishkek often lived with other family members but remained registered at another address in the hope that their property would soon be demolished for slum clearance purposes (Dzhunkovskii, 1982). Such slum clearances would entitle the propiska holder to a new home typically in one of the city's betterequipped micro-districts (mikroraions) located outside of Bishkek's city centre. ${ }^{7}$

Once registered somewhere, the property right under Soviet law, although still legally a 'tenancy', became relatively secure. As Höjdestrand (2003) notes, the municipality could not evict a tenant, even if they had failed to pay rent, unless cheaper accommodation was offered. The Soviet tenancy agreement therefore resembled a property right close to Western versions of private homeownership (Marcuse, 1996). During the privatisation era of the early 1990s, following the collapse of the Soviet Union, the important property meanings of the propiska crystallised as it served as documentary proof for transferring ownership of property from the state to the individual sitting tenant (see Hatcher, forthcoming). The importance of the propiska during the initial period of privatisation contrasts with the previous discussion on its framing as a 'legacy' or a 'throwback' that is holding back the economic development of Kyrgyzstan. Different representations of the propiska are unfolding. Although framed by groups pushing for reform as a Soviet institution, the propiska was appropriated as an important tool in instigating the transition towards capitalist logics in Kyrgyzstan. The 
propiska was converted into forms of individual ownership designed to kick-start a free-market economy. Rather than reading the propiska in a reductionist way as an 'alien' remnant of the past 'out of place' in today's new Kyrgyzstan, it is pertinent to observe what Golubchikov et al. (2014: 618) highlight are the 'hybrid spatialities' of postsocialist urban change. Through different representations and understandings, the propiska works as a combination of 'mutual embeddedness of the legacies of socialism and the workings of neoliberal capitalism' that 'jointly produce the hybrid spatialities of transition' which expose the 'root causes of uneven development.'

The initial appropriation of the propiska by capitalist logics, and in particular changing meanings of property, is also important for understanding how new spatial inequalities have arisen in post-socialist Bishkek. In the Soviet period the mechanism of the propiska restricted internal migration, yet as a local lawyer noted:

During the Soviet period the problems that have now appeared as a result of independence did not exist. The residents of far away provinces were able to live well on their salaries ... There was no need to leave or migrate from your home in search of somewhere better. The entire [propiska] procedure was also stricter. People simply did not try to move, so there was not a very large problem with internal migration. And in those same rural regions that people are now leaving, practically all the resources necessary to build a house and raise a family were present so people did not have to leave.

Wider processes of post-socialist transformation, and especially de-industrialisation and agricultural restructuring in rural areas following the suspension of subsidies that existed during the Soviet period and the resultant increase in the number of migrants moving to Bishkek, has re-spatialised the workings of the propiska. Administrative procedures for registering have remained largely unchanged yet the previous strict enforcement of protecting the city from 'capitalist expansion' is no longer relevant. This hybrid spatiality through the combination of legacy and transition equates to contemporary forms of inequality that unfold in the city.

Post-socialist inequalities embedded in the propiska system are structured around its ongoing procedural aspects (the process of obtaining a propiska) together with its 'mutation' towards new urban landscapes of property ownership. As with most post-socialist cities (Marcuse, 1996), programmes privatising state housing have created high rates of private ownership. Residents of Bishkek who lived and grew up in the city prior to the dissolution of the Soviet Union often have no problem with registering their address in the city. Those residents who received ownership of their property during the privatisation era can use their property documents to register against their address. Similarly, migrants who come from outside of Bishkek and purchase a property in the city can also register themselves with the local authorities using their newly acquired property documents. For some migrants, however, coming from other regions (oblasts) purchasing a property in the city is inconceivable where the average price per square metre even outside the city centre was $\$ 700$ in 2013 (Numbeo, 2013). As with other postsocialist cities, the development of the housing market has led to the increase of high-rise elite housing (elitka) by foreign construction companies in the city centre, while the building of affordable housing in the country has almost frozen (UNECE, 2010). Migrants often rent a property or, owing to the high cost of renting, informally 'buy' a cheaper property on an 'illegal' novostroika established after the political unrest of the Tulip Revolution in 2005, or alternatively purchase 
an 'illegal' plot of land within one of the formalised settlements. ${ }^{8}$ Landlords often refuse, however, to register tenants as this increases their tax liability and utility expenses they are liable to pay. Moreover, the importance of the propiska in transferring property ownership during the privatisation period remains in the minds of property owners today who often believe that registration of a tenant could confer partial ownership to that registered tenant. The illegal status of a property in a squatter settlement also means that the 'squatter' has no official address to register against. As a result, tenants and residents living in 'illegal' squatter settlements or on 'illegal' land plots in formalised settlements on the city's periphery often experience difficulties in fulfilling the bureaucratic obstacles required to obtain the propiska and subsequently in accessing urban services in the city through official channels.

As Golubchikov and Phelps (2011: 429) note in echoing Burawoy and Verdery (1999), 'the internalisation of the neoliberal doctrine has been blended with the persistence of socialist elements, which may now play a very different role than in the past.' As property rights have transformed in Bishkek with the rollout of housing privatisation and consequently the transfer of ownership from the state to sitting tenants, the enduring persistence of the propiska regime has blended and mutated with these neoliberal logics. The registration process is now conceived through property ownership, which in turn marginalises those in the city, often migrants, who rent or live in an 'illegal' settlement or an 'illegal' plot of a formalised settlement. This institutional hybridisation of past and present has taken on a spatial formation in the city through the visible geographical distribution of illegal and formalised settlements on the outskirts and the less visible legal spaces of tenants living in both the planned and unplanned areas of Bishkek.

\section{Conclusion}

If 'after transition' is to contemplate postsocialist change that is fixated on East and Central Europe, 'after institutional transition' over-emphasises the official changes altering or that have altered socialist institutions while falling short of recognising the embedded practices that continue to be performed at the everyday level by local actors. The mechanisms of such institutions still rely on individuals that have worked in both the Soviet and the present period, material remnants remain as before and attitudes continue to persist. Studies on change in post-socialist cities have the possibility to provide, therefore, an understanding of how official policies are 'domesticated' in neoliberal contexts as a counterpoint to conceiving transformation from a 'top-down' perspective. It is the blending of persisting socialist elements and the internalisation of a neoliberal doctrine that consequently results in a 'mutation' of the socialist institution shifting it into a contemporary format (Golubchikov and Phelps, 2011: 428) - a format that contradictorily bears multiple changes and continuities.

In Kyrgyzstan, the formal changes to domestic legislation have reshaped the institutional workings of the propiska system yet fallen short of dismantling it altogether. These changes have resulted in a postsocialist version of mobility in Kyrgyzstan today, which, in turn, has reshaped urban space. As migration from one area of the country to another is no longer so stringently restricted as it was in the Soviet era, a new version of mobility reflects an ongoing division between the increasingly poorer rural areas of the country and the comparatively better-off and privileged city residents. Whereas in the Soviet period this urbanrural division was stringently maintained through workings of the propiska system together with greater investment and 
employment opportunities, the system's partial changes and de-industrialisation have resulted in spatial inequalities unfolding in an intra-urban context. Rural migrants are not restricted from physically moving to the city, yet accessing basic state provisions in Bishkek is complicated by heavily bureaucratic procedures that have become embedded within new understandings of property.

There is a mutual and interdependent relationship between the spatial characteristics of the city and institutional processes. The relaxation of the propiska's stringent approach towards internal migration led to the increase of the city's migrant population which, in turn, formed new spatialities of informality on the edge of the city together with an increased demand for rentable properties in the city. Moreover, the changes in property relations as a result of privatisation reformed how the procedure of registration was administered favouring property owners in comparison to those individuals with other property interests.

While the spatial formation of informal settlements emerged in part as a result of reducing the restrictions of the propiska, the increase of these settlements on the city's edge, in particular, serves as a reason for some groups to advocate reducing these restrictions further or abolishing the propiska given the problems that those residents have in accessing public services through official channels. On the other hand, the visual presence of such settlements and internal migrants in the city has led to other interest groups arguing for the preservation or strengthening of the propiska. These groups continue to see the propiska as a tool to protect the city from 'overcrowding' and 'invasion' from migrants. The propiska system has therefore become a subtle mixture of real and imagined characteristics, which continue to shape its future pathways. These debates over the propiska are produced through the city: by the close proximity of internal migrants living in illegal settlements and 'old-timers' as well as through perceptions of who has a right to live in the city.

In analysing aspects of post-socialist urban change, in this paper we aimed to emphasise the ongoing aspects of institutional transition by expanding on the meaning of the 'institution' beyond initial political and economic programmes implemented in the 1990s. In doing so, we take on a more localised understanding of the institution as a means to understand how it is shaped, produced and 'domesticated' by actors. We acknowledge not only how institutional change has affected spatial change in the city (Taşan-Kok, 2006) but also, with the simultaneity of multiple transitions (Sýkora and Bouzarovski, 2012), how urban change - in our case, the privatisation of housing stock has become incorporated into the (re)workings of the institution thus forming a reciprocal rather than sequential relationship between city and institution. Drawing on the combination of multiple framings and the embedded nature of transition we witness the unfolding of 'hybrid spatialities' as the paradox of legacy and change reveals a mutated institution undergoing the continuous process of transition.

\section{Acknowledgements}

The comments of Matthew Gandy, Urs Geiser, Anita Ghimire, Kathrin Hörschelmann, Jarkyn Samanchina, and participants at the 2013 Cities After Transition (CAT) conference in Tbilisi, Georgia are greatly appreciated. We are also especially grateful to three anonymous reviewers from Urban Studies for their comments on an earlier draft.

\section{Funding}

The research for this publication was conducted within the framework of the Swiss National 
Centre of Competence in Research (NCCR) North-South.

\section{Notes}

1. All foreign terms are in Russian unless stated otherwise.

2. From 1926 until Kyrgyzstan's independence in 1991, Bishkek was known as Frunze. The propiska system was enacted in Frunze in 1939 by a decree of the Executive Committee of the Frunze City Soviet of the Kyrgyz Soviet Socialist Republic, 29 April 1939.

3. As the Organisation for Security and Cooperation in Europe (OSCE) (2009: 5) notes, in many countries, "citizens are required to register their place of residence with the relevant authorities, who use the system for the planning and delivery of state services and to contact people.'

4. The meaning of kulak is transient. Kulaks were broadly identified as wealthy peasants who emerged after the emancipation of the serfs and then later resisted Stalin's campaign of farming collectivisation.

5. Although these are official statistics and unlikely to match the reality, they serve as an indicator of the increase of the city's population, and specifically its population originating from rural areas, as the typically 'urban' ethnic Russian population were leaving Kyrgyzstan.

6. Out of a study of 28 cities conducted in 1979, three Central Asian cities had the highest levels of overcrowding (Bishkek, Tashkent and Dushanbe) with per capita living space of 6.9, 6.8 and $6.6 \mathrm{~m}^{2}$ respectively. By comparison, Moscow's average per capita living space was $11.2 \mathrm{~m}^{2}$ (Morton and Stuart, 1984).

7. Micro-districts became a major element of urban planning in Soviet cities from the 1950s. These neighbourhood units consisted of a group of large standardised residential buildings, with shops and services on the ground floor. The districts were built quickly and cheaply using concrete panel technology. In Bishkek, construction of these neighbourhoods first began in 1970 following the development of standardised four-, five-, and ninestorey housing designs.
8. See Hatcher (2015) on the meaning of 'illegality' in relation to novostroikas on the outskirts of the city.

\section{References}

Alexander C, Buchli V and Humphrey C (2007) Urban Life in Post-Soviet Asia. London: UCL Press.

Amin A and Thrift N (2002) Cities: Reimagining the Urban. Cambridge: Polity Press.

Andrusz G, Harloe M and Szelenyi I (1996) Cities After Socialism: Urban and Regional Change and Conflict in Post-Socialist Societies. Oxford: Blackwell.

Azimov U and Azimov T (2009) Discrimination Against Internal Migrants in the Kyrgyz Republic: Analysis and Recommendations. Bishkek: Social Research Centre.

Bovt G (2013) The propiska sends Russia back to the USSR. The Moscow Times, 17 January.

Buckley C (1995) The myth of managed migration: Migration control and market in the Soviet period. Slavic Review 54(4): 896-916.

Burawoy M and Verdery K (1999) Introduction. In: Burawoy M and Verdery K (eds) Uncertain Transition: Ethnographies of Change in the Postsocialist World. Oxford: Rowman and Littlefield Publishers, Inc, pp. 1-18.

Creed GW (1999) Deconstructing socialism in Bulgaria. In: Burawoy M and Verdery K (eds) Uncertain Transition: Ethnographies of Change in the Postsocialist World. Oxford: Rowman and Littlefield Publishers, Inc, pp. 223-243.

Darieva T, Kaschuba W and Krebs M (2012) Urban Spaces after Socialism: Ethnographies of Public Places in Eurasian Cities. Frankfurt: Campus Verlag.

Dzhunkovskii V (1982) Sobliudat' pasportnii rezhim. Vecherniy Frunze, 28 October.

Flynn M and Kosmarskaya N (2012) Exploring 'north' and 'south' in post-Soviet Bishkek: Discourses and perceptions of rural-urban migration. Nationalities Papers 40(3): 453-471.

Flynn M, Kosmarskaya N and Sabirova G (2014) The place of memory in understanding urban change in central Asia: The cities of Bishkek and Ferghana. Europe-Asia Studies 66(9): 1501-1524. 
French RA and Hamilton FE (1979) The Socialist City. Chichester: Wiley.

Gentile M and Tammaru T (2006) Housing and ethnicity in the post-Soviet city: Ust'-Kamenogorsk, Kazakhstan. Urban Studies 43(10): 1757-1778.

Gentile M, Tammaru $\mathrm{T}$ and van Kempen $\mathrm{R}$ (2012) Heteropolitanization: Social and spatial change in Central and East European Cities. Cities 29(5): 291-299.

Golubchikov O and Phelps N (2011) The political economy of place at the post-socialist urban periphery: Governing growth on the edge of Moscow. Transactions of the Institute of British Geographers 36: 425-440.

Golubchikov O, Badyina A and Makhrova A (2014) The hybrid spatialities of transition: Capitalism, legacy, and uneven urban economic restructuring. Urban Studies 51(4): 617-633.

Grubbauer M and Kusiak J (2012) Chasing Warsaw: Socio-Material Dynamics of Urban Change since 1990. Frankfurt: Campus.

Haase A, Steinführer A, Kabisch S, et al. (2011) Residential Change and Demographic Challenge: The Inner City of East Central Europe in the 21st Century. Surrey: Ashgate.

Hann CM, Humphrey C and Verdery K (2002) Introduction: Postsocialism as a topic of anthropological investigation. In: Hann CM (ed.) Postsocialism: Ideals and Ideologies and Practices in Eurasia. London: Routledge, pp. $1-28$.

Hansen TB and Stepputat F (2001) States of Imagination. Durham: Duke University Press.

Hatcher C (2015) Illegal geographies of the state: The legalisation of a 'squatter' settlement in Bishkek, Kyrgyzstan. International Journal of Law in the Built Environment 7(1): 39-54.

Hatcher C (forthcoming) Globalising homeownership: Housing privatisation schemes and the private rental sector in post-socialist Bishkek, Kyrgyzstan. International Development Planning Review.

Herrschel T (2007) Between difference and adjustment: The re-/presentation and implementation of post-socialist (communist) transformation. Geoforum 38: 439-444.

Höjdestrand T (2003) The Soviet-Russian production of homelessness. Available at: http://
www.anthrobase.com/Txt/H/Hoejdestrand_T_ 01.htm (accessed 12 February 2012).

Hörschelmann K and Stenning A (2008) Ethnographies of postsocialist change. Progress in Human Geography 32(3): 339-361.

Ibold H (2010) Disjuncture 2.0: Youth, internet use, and cultural identity in Bishkek. Central Asian Survey 29(4): 521-535.

Kessler G (2001) The passport system and state control over population flows in the Soviet Union, 1932-1940. Cahiers du monde russe 42(2-4): 477-504.

Leetmaa K, Tammaru T and Anniste K (2009) From priority-led to market-led sub-urbanisation in a post-communist metropolis. Tijdschrift voor Economische en Sociale Geografie 100(4): 436-453.

Light M (2012) What does it mean to control migration? Soviet mobility policies. Comparative Perspective, Law \& Social Inquiry 37(2): 395-429.

Marcuse P (1996) Privatization and its discontents: Property rights in land and housing in the transition in Eastern Europe. In: Andrusz G, Harloe M and Szelenyi I (eds) Cities After Socialism: Urban and Regional Change and Conflict in Post-Socialist Societies. Oxford: Blackwell, pp. 119-191.

Marcuse P (2011) Post-socialist property rights? Whose property rights, to what and how? Urban Studies 48(3): 605-608.

Matthews M (1993) The Passport Society: Controlling Movement in Russia and the USSR. Oxford: Westview Press.

Morton H (1980) Who gets what, when and how? Housing in the Soviet Union. Soviet Studies 32(2): 235-259.

Morton H and Stuart R (1984) The Contemporary Soviet City. New York: Sharpe.

National Statistical Committee of the Kyrgyz Republic (2009) Population and Housing Census of the Kyrgyz Republic of 2009. Bishkek: National Statistical Committee of the Kyrgyz Republic.

North DC (1990) Institutions, Institutional Change, and Economic Performance. Cambridge: Cambridge University Press.

Numbeo (2013) Cost of living. Available at: http://www.numbeo.com/cost-of-living/ (accessed 3 February 2014). 
OSCE (Organisation for Security and Co-operation in Europe) (2009) Guidelines on Population Registration. Warsaw: OSCE.

Sanghera B, Satybaldieva E, Rodionov A, et al. (2012) Illegal settlements and city registration in Kyrgyzstan and Kazakhstan: Implications for legal empowerment, politics, and ethnic tensions. Central Eurasia Project. Occasional Paper Series 5, Open Society Foundations.

Schaible DS (2001) Life in Russia's 'closed city': Moscow's movement restrictions and the rule of law. New York University Law Review 76: 344-373.

Schroeder P (2010) Urbanizing Bishkek: Interrelations of boundaries, migration, group size and opportunity structure. Central Asian Survey 29(4): 453-467.

Smith A and Rochovská A (2007) Domesticating neo-liberalism: Everyday lives and the geographies of post-socialist transformations. Geoforum 38(6): 1163-1178.

Sovetskaya Kirgizia (1948) Ob Osnovnykh Obyazannostyakh Grazhdan, Upravlyaiushchikh Domami, Komendantov, Domovladed'tsev, Rukovoditelei Uchrezhdenia i Predpriyatii po Sobliuleniu Pasportnogo Rezhima i Pravil Propiski i Vipiski [About the main duties of citizens, house managers, hostel wardens, house owners, heads of institutions and enterprises on observance of passport system and rule of registration and striking off from the list of tenants]. Sovetskaya Kirgizia, 20 August.

Stanilov K (2007) Housing trends in Central and Eastern European cities during and after the period of transition. In: Stanilov K (ed.) The Post-socialist City. Dordrecht: Springer, pp. 173-190.

Stark D (1996) Recombinant property in East European capitalism. American Journal of Sociology 101(4): 993-1027.

Stark D and Bruszt L (2001) One way or multiple pathways: For a comparative sociology of
East European capitalism. American Journal of Sociology 106(4): 1129-1137.

SRS (State Registration Service) (2011) Kontseptsia rasvita Gosudarstevennoi registratsionnoi sistemi Kirgiskoi Respubliki na 2011-2021gg. Bishkek: SRS.

Stenning A (2000) Placing (post-) socialism: The making and remaking of Nowa Huta, Poland. European Urban and Regional Studies 7(2): 99-118.

Stenning A, Smith A, Rochovská A, et al. (2010) Domesticating Neo-Liberalism: Spaces of Economic Practice and Social Reproduction in Post-Socialist Cities. Oxford: Wiley-Blackwell.

Sýkora L and Bouzarovski S (2012) Multiple transformations: Conceptualising the postcommunist urban transition. Urban Studies 49(1): 43-60.

Taşan-Kok T (2006) Institutional and spatial change. In: Tsenkova S and Nedović-Budić Z (eds) The Urban Mosaic of Post-Socialist Europe: Space, Institutions and Policy. Heidelberg: Physica-Verlag, pp. 51-70.

Toktosunov I (1975) Molotkastyi, Sernasty! Sovetskaya Kirgizia, 23 November.

Tsenkova S and Nedović-Budić Z (2006) The Urban Mosaic of Post-Socialist Europe: Space, Institutions and Policy. Heidelberg: PhysicaVerlag.

USAID (2011) Property Rights and Resource Governance. Kyrgyzstan: USAID.

Vecherniy Frunze (1990) Propiska v stolitse, chto novogo? Vecherniy Frunze, 19 April.

Verdery K (1996) What was Socialism, and What Comes Next? Princeton: Princeton University Press.

Verdery K (1999) Fuzzy property: Rights, power, and identity in Transylvania's decollectivization. In: Burawoy $\mathrm{M}$ and Verdery $\mathrm{K}$ (eds) Uncertain Transition: Ethnographies of Change in the Postsocialist World. Oxford: Rowman and Littlefield Publishers, Inc, pp. 53-81. 